\title{
Smooth Muscle Cell
}

National Cancer Institute

\section{Source}

National Cancer Institute. Smooth Muscle Cell. NCI Thesaurus. Code C13001.

An elongated spindle-shaped contractile cell, peculiar to an involuntary muscle, containing a single nucleus and long itudinally arranged myofibrils. 